Journal of Nonformal Education and Community Empowerment

Volume 1 (1): 75-86, Juni 2017

Available at http://journal.unnes.ac.id/sju/index.php/jnfc

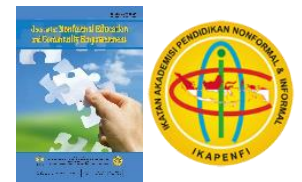

p-ISSN 2549-1539

e-ISSN $2579-4256$

\title{
Evaluasi Penyelenggaraan Pembinaan Pelatihan Keterampilan di Lembaga Kursus dan Pelatihan Yuwita Tasikmalaya
}

\author{
Wiwin Herwina $^{凶}$
}

Program Studi Pendidikan Luar Sekolah, FKIP Universitas Siliwangi Tasikmalaya

\begin{tabular}{l} 
Info Artikel \\
\hline Sejarah Artikel: \\
Diterima Maret 2017 \\
Disetujui Mei 2017 \\
Dipublikasikan Juni 2017
\end{tabular}

Keywords:

evaluation; skill training; course and training institute

\begin{abstract}
Abstrak
Tujuan penelitian ini adalah mendeskripsikan evaluasi hasil penyelenggaraan pembinaan pelatihan keterampilan di LKP Yuwita. Responden berjumlah 30 orang yang berasal dari lulusan LKP Yuwita. Responden diambil secara random dengan fokus pada lulusan yang pernah mengikuti pelatihan keterampilan di LKP Yuwita. Metode yang digunakan adalah deskriptif kuantitatif. Instrumen pengumpulan data menggunakan angket. Hasil penelitian yang sebagian besar melibatkan lulusan usia produktif rata-rata berpendidikan SMP dan sebagian besar telah mendapatkan pekerjaan. Latar belakang mengikuti pelatihan sebagian besar sebagai bekal untuk mendapatkan pekerjaan. Metode yang diinginkan menggunakan ceramah dan demonstrasi dengan materi ditekankan pada praktik. Cara belajar mereka lebih condong pada belajar bersama teman. Instruktur telah membimbing dengan sungguh-sungguh. Lulusan berharap LKP Yuwita bisa menyelenggarakan pelatihan keterampilan secara berkelanjutan.
\end{abstract}

\begin{abstract}
The purpose of this study is to describe the evaluation of the results of training skills training in LKP Yuwita. Respondents amounted to 30 people who came from LKP Yuwita graduates. Respondents were taken randomly by focusing on graduates who had attended skills training at LKP Yuwita. The method used is descriptive quantitative. The instrument of data collection using questionnaire. The results of the study, which mostly involves graduates of average productive age junior high school and most have gained employment. The background follows the training mostly as a provision to get a job. The desired method of using lectures and demonstrations with material is emphasized in practice. The way they learn is more inclined to learn with friends. The instructor has been guiding earnestly. Graduates hope LKP Yuwita can hold ongoing skills training.
\end{abstract}

Alamat korespondensi:

E-mail: lkp.yuwita@yahoo.co.id 


\section{PENDAHULUAN}

Pendidikan diselenggarakan untuk meningkatkan modal manusia di era global saat ini. Mengantisipasi perubahan-perubahan yang begitu cepat serta tantangan yang semakin besar dan kompleks, tidak ada jalan lain bagi lembaga pendidikan untuk mengupayakan segala cara dalam meningkatkan daya saing lulusan serta produk-produk akademik lainnya, antara lain dicapai melalui perbaikan sistem pendidikan. Upaya ini diharapkan dapat melahirkan manusia-manusia yang berkualitas sebagai bagian dari suatu masyarakat yang terus belajar (learning society). Hal ini sejalan dengan pendapat Anwar (2004:5) bahwa "Memasuki era globalisasi di abad ke-21 diperlukan suatu paradigma baru dalam sistem pendidikan dunia, dalam rangka mencerdaskan umat manusia dan memelihara persaudaraan". Sedangkan menurut International Commission on Education for the Twenty-First Century \& Delors (1996:19), "Although people need to take every opportunity for learning and self-improvement, they will not be able to make good use of all these potential resources unless they have received a sound basic education". Meskipun bagaimanapun orang perlu mengambil setiap kesempatan untuk belajar dan memperbaiki diri, mereka tidak akan dapat memanfaatkan semua sumber daya potensial kecuali jika mereka telah mendapatkan pendidikan dasar yang baik.

Salah satu lembaga pendidikan yang memiliki perhatian penuh terhadap pengembangan manusia atau lulusan yang berkualitas adalah pendidikan luar sekolah. Trisnamansyah (Kamil, 2012:30) menyatakan bahwa "Ilmu pendidikan luar sekolah diartikan sebagai ilmu yang secara sistematik mempelajari interaksi sosial-budaya antara warga belajar sebagai objek dengan sumber belajar dalam rangka mencapai tujuan-tujuan pendidikan yang diinginkan, dengan menekankan pada pembentukan kemandirian, dalam rangka belajar sepanjang hayat". Hal ini sejalan dengan tujuan pendidikan nasional dalam Undangundang Sistem Pendidikan Nasional No. 20 tahun 2003 bahwa, "Pendidikan adalah usaha sadar dan terencana untuk mewujudkan suasana belajar dan proses pembelajaran agar peserta didik secara aktif mengembangkan potensi dirinya untuk memiliki kekuatan spiritual keagamaan, pengendalian diri, kepribadian, kecerdasan, akhlak mulia, serta keterampilan yang diperlukan dirinya, masyarakat, bangsa dan negara" (Bab I Ketentuan Umum Pasal 1 UU SPN No. 20/2003).

Pembangunan Nasional ditujukan kepada terlaksananya masyarakat adil dan makmur yang merata secara materiil dan sprituil. Pembangunan tidak hanya mengejar kemajuan lahiriah atau kepuasan bathiniah saja, melainkan keselarasan dan keseimbangan keduanya, bahwa pembangunan itu bukan untuk sesuatu golongan atau sebagian dari masyarakat, tetapi untuk seluruh masyarakat, dan harus benar-benar dirasakan oleh seluruh rakyat Indonesia sebagai perbaikan tingkat hidup yang berkeadilan sosial, yang menjadi tujuan dan cita-cita kemerdekaan kita (GBHN, 1993). Yang menjadi perhatian pada hakikatnya pembangunan nasional adalah untuk seluruh lapisan masyarakat Indonesia, ini berarti yang akan dibangun adalah manusia dan masyarakat Indonesia dengan segala aspek-aspeknya dan bertujuan untuk meningkatkan kesejahteraan sosial masyarakat Indonesia.

Setiap warga negara berkewajiban untuk berpartisipasi dalam proses pembangunan serta dapat menikmati hasil pembangunan tersebut. Pengertian warga negara disini jelas tidak mengecualikan pemuda-pemudi yang putus sekolah (drop out) juga mempunyai hak yang sama dengan anggota masyarakat lainnya untuk menikmati hak-hak kemanusiaan yang asasi, serta berhak mendapatkan pekerjaan yang sesuai bagi mereka. Seperti yang tercantum dalam Undang-undang Dasar 1945 pasal 27, bahwa "Setiap warga negara berhak mendapatkan pekerjaan dan penghidupan yang yang layak bagi kemanusiaan". Dalam memperluas kesempatan untuk memperoleh pendidikan, perlu diperhatikan kesempatan belajar dan kesempatan meningkatkan keterampilan bagi pemuda-pemudi yang putus sekolah. Kesemuanya itu dapat dicapai di lembagalembaga kursus, ataupun di pendidikan 
nonformal lainnya, seperti paket A, paket B dan paket C.

Lembaga Kursus dan Pelatihan (LKP) Yuwita adalah suatu lembaga keterampilan dan pelatihan yang memfasilitasi mereka pemudapemudi putus sekolah untuk tetap eksis menyambut masa depannya. Pemuda-pemudi putus sekolah formal merupakan bagian dari generasi yang harus memperoleh kesempatan untuk mengembangkan dirinya sesuai dengan potensi yang ada pada mereka. Generasi yang seluruhnya mengambil bagian dalam pembangunan, pengembangan potensi itu akan lebih berhasil apabila memperoleh kesempatan pendidikan secara serasi dan layak. Kondisi ini tentu menjadi keprihatinan bagi semua. Setidaknya hal ini dapat ditangani bekerjasama dengan pemerintahan, baik dengan Dinas Tenaga Kerja maupun dengan Dinas Pendidikan khususnya pendidikan nonformal. Kelembagaan pendidikan nonformal yang salah satu diantaranya adalah lembaga kursus dan pelatihan sebagai subtitusi atau pengganti bagi pendidikan persekolahan (formal) tugasnya yaitu untuk membina, melatih para pemudapemudi yang putus sekolah agar mereka memiliki keterampilan dan kesempatan kerja sesuai dengan bakat kemampuannya, yang pada akhirnya dari keterampilan itu menjadi suatu bekal bagi dirinya sendiri juga bagi keluarganya.

Meski bagaimana pun, anak/pemudapemudi putus sekolah adalah anak bangsa yang menjadi tanggungan negara. Karena setiap warga negera Indonesia berhak memperoleh pendidikan yang layak. Jika mereka tidak mampu berkembang di lingkungan pendidikan formal, maka lingkungan pendidikan nonformal dalam hal ini lembaga kursus dan pendidikan tentunya siap sebagai wadah mengembangkan anak bangsa tersebut. Dalam penyelenggaraannya, lembaga kursus dan pelatihan selakyaknya juga mampu mengetahui kemampuan lembaganya dalam proses penyelenggaraan pendidikan. Hal demikian diperlukan adanya penilaian dan pengakuan dari beberapa pihak. Selain adanya akreditasi sebagai penilaian kelayakan penyelenggaraan suatu lembaga, perencanaan dan pengukuran juga diperlukan dengan melibatkan opini dari lulusan. Hal ini sangat penting demi keberlanjutan lembaga dalam proses penyelenggaraanya sesuai dengan yang dibutuhkan masyarakat terutama pangsa kerja. Hal ini jelas, bahwa lembaga kursus dan pelatihan orientasi utamanya adalah membekali warga belajar untuk memperoleh keterampilan serta mampu meluluskan warga belajarnya untuk siap menghadapi tantangan dunia kerja. Oleh karenanya, opini lulusan diperlukan sebagai evaluasi penyelenggaraan lembaga agar relevan dengan program yang diselenggarakannya. Pendidikan menyangkut pada proses pembelajaran, yangmana dalam sistem pembelajaran juga membutuhkan berbagai komponen yang itu dapat diterapkan secara efektif dan efisien yang selaras dengan yang dibutuhkan oleh warga belajarnya. Kondisi demikian yang kemudian diperlukan adanya penelitian mengenai evaluasi penyelenggaraan lembaga melalui program yang diselenggarakan. Penelitian yang diadakan di Lembaga Kursus dan Pelatihan Yuwita Tasikmalaya Jawa Barat bertujuan mendeskripsikan hasil evaluasi penyelenggaraan pembinaan pelatihan keterampilan. Fokus penelitian mencakup latar belakang lulusan, motivasi mengikuti pelatihan, metode, media dan materi yang pernah diperoleh saat pelatihan, serta kemampuan dalam memahami materi.

\section{METODE}

Penelitian ini menggunakan metode deskriptif kuantitatif. Sebagaimana "Penelitian memusatkan pada pemecahan masalah-masalah yang ada pada masa sekarang, dan data-data yang dikumpulkan" (Surakhmad, 1979:140). Penelitian dilakukan di LKP Yuwita Tasikmalaya Jawa Barat. Responden berjumlah 30 orang yang berasal dari lulusan LKP Yuwita. Responden ini dulunya adalah warga belajar di LKP Yuwita yang berasal dari pemuda-pemudi putus sekolah yang mengikuti pembinaan pelatihan keterampilan. Responden diambil dengan teknik random dan dikhususkan pada mereka yang mengikuti pelatihan keterampilan tata rias pengantin. Instrumen pengumpulan 
data menggunakan angket. Analisis data menggunakan deskriptif kuantitatif yang mengacu pada fokus penelitian mengenai latar belakang lulusan yang mengisi angket, motivasi mengikuti pelatihan, penggunaan metode, media dan materi saat pelatihan berlangsung, serta kemampuan pemahaman materi yang disampaikan oleh instruktur. Hasil penelitian ini digunakan sebagai identifikasi kebutuhan pengembangan LKP Yuwita, dengan demikian dimaksud agar LKP Yuwita dapat mengelola lembaga dengan kegiatan pelatihan secara berkesinambungan berdasarkan pada kebutuhan masyarakat atau pasar kerja.

\section{HASIL DAN PEMBAHASAN}

Berawal dari usaha salon kecantikan rambut dan tata rias pengantin pada tahun 1988 Yuwita salon yang bergerak di bidang kecantikan mulai berkembang menjadi suatu lembaga pendidikan keterampilan dan pelatihan pada tahun 2006. Lembaga pendidikan keterampilan adalah bagian dari pendidikan luar sekolah yang berperan banyak dalam menyiapkan sumber daya manusia untuk memiliki sikap mental, minat, bakat, dan keterampilan serta berkemampuan sehingga memiliki peran cukup penting, strategis dan menjadi bagian integral dari pembangunan bangsa. Peranan strategis tersebut tidaklah mungkin dapat berkembang sesuai dengan tuntutan masyarakat. Seandainya tanggung jawab dan pembinaannya hanya di lakukan sebatas kemampuan penyelenggara semata, tetapi harus dengan political will pemerintah seperti termasuk dalam UU Sistem Pendidikan Nasional no. 20 tahun 2003 dan PP no. 73 tahun 1991 diharapkan dapat mampu menjembatani berbagai kebutuhan dan permasalahan penyelenggara lembaga kursus dan pelatihan maupun oleh masyarakat sebagai peserta baik oleh penyelenggara lembaga pendidikan kursus maupun oleh masyarakat sebagai peserta didik atau calon peserta didik. Dari harapan tersebut, LPK Yuwita bertekad untuk mencetak hasil lulusan yang handal (kompeten) bukan hanya di daerah tapi sampai ke luar daerah.
Dalam rangka mencetak hasil lulusan yang berkualitas pelayanan kepada masyarakat tentu saja lebih ditingkatkan, dan pembinaan pelatihan bukan hanya untuk masyarakat yang mampu, yang tidak mampu pun harus dibina termasuk para pemuda-pemudi yang putus sekolah. Tujuan pada dasarnya sama untuk meningkatkan kesejahteraan hidup dan mencetak manusia mandiri di bidang keakhliannya, sehingga pada akhirnya menjadi profesi dan dapat meningkatkan derajat hidupnya.

\section{Identitas Responden}

Responden dalam penelitian ini sebanyak 30 orang lulusan yang dulunya mengikuti pembinaan melalui pelatihan keterampilan di LKP Yuwita, terdiri dari para pemuda-pemudi putus sekolah. Adapun gambaran umum responden dapat dilihat dari beberapa segi, antara lain umur responden, status perkawinan, jenis kelamin dan dan pendidikan terakhir. Untuk lebih mengetahui identitas responden dapat dilihat dari masing-masing tabel berikut ini.

Pada tabel 1 menunjukkan bahwa, seluruh responden (lulusan LKP Yuwita) termasuk golongan usia produktif yang berarti secara potensial mereka mempunyai potensi untuk bekerja. Berdasarkan kriteria usia produktif, paling banyak mereka pada usia 2125. Artinya, pengisi angket dalam penelitian ini adalah mereka yang benar-benar pada usia produktif ideal (dengan artian tidak terlalu muda juga tidak terlalu tua saat usia produktif). Dengan demikian, responden di sini adalah mereka yang telah memiliki usia kemantapan berfikir sehingga akan memberikan pendapat/opini yang cukup dalam memahami pengisian angket.

Tabel 2 menunjukkan bahwa responden (lulusan LKP Yuwita) lebih banyak berjenis kelamin perempuan sebesar $75 \%$, yaitu tiga kali jumlah responden laki-laki, sedangkan responden laki laki 25\%. Hal ini menunjukkan bahwa perempuan sekarang sudah lebih maju lebih berpikir kreatif dengan memiliki keahlian dan keterampilan dapat dijadikan bekal untuk 
menghidupi keluarganya dan tidak lagi bergantung pada orang lain (mandiri).

Tabel 3 menunjukkan tingkat pendidikan lulusan LKP Yuwita paling banyak adalah mereka yang telah tamat $\mathrm{SMP} /$ sederajat yang mencakup mereka 70\% telah tamat SMP dan 15\% tidak lulus SMU. Tentunya mereka yang tidak lulus SMU adalah putus sekolah saat menginjak sekolah SMU/sederajat. Dapat dinyatakan pula mereka yang telah lulus SMP sejumlah 85\%, sedangkan secara keseluruhan yang lulus SD berjumlah 15\%. Jumlah yang lulus SD/sederajat adalah mereka yang $10 \%$ tidak tamat/putus sekolah waktu di SMPnya, dan 5\% yang sudah tamat SD tapi tidak melanjutkan pada jenjang SMP. Karena rendahnya tingkat pendidikan mereka, maka mereka mengikuti pelatihan yang diselenggarakan LKP Yuwita. Kondisi demikian diartikan bahwa adanya kurang mampuan mereka dalam mengenyam pendidikan formal. Lulusan ini saat menjadi warga belajar di LKP Yuwita mayoritas adalah lulusan SMP yang pada umumnya kurang memiliki potensi untuk bergelut di dunia kerja. Oleh karenannya, dengan adanya pembinaan pelatihan keterampilan dapat digunakan bekal sekaligus kemampuan yang memadai untuk bisa mengakses dunia kerja yang anti syarat dengan intelegensi atau tingkat pendidikan yang tinggi. Dengan demikian, keterampilan tadi dapat digunakan untuk menghasilkan karya yang bisa dipasarkan untuk menghidupi dirinya beserta keluarga dan tidak tergantung kepada orang lain.

Tabel 1. Penggolongan Lulusan LKP Yuwita Berdasarkan Usia

\begin{tabular}{|c|c|c|c|}
\hline No & Kelompok Umur (Tahun) & Jumlah & Prosentase $\%$ \\
\hline 1 & Kurang dari 15 & - & - \\
\hline 2 & $16-20$ & 10 & $35 \%$ \\
\hline 3 & $21-25$ & 15 & 50,00 \\
\hline 4 & $26-30$ & 5 & $15 \%$ \\
\hline \multicolumn{2}{|r|}{ Jumlah } & 30 & 100 \\
\hline
\end{tabular}

Sumber: Hasil Angket 2016.

Tabel 2. Penggolongan Lulusan LKP Yuwita Berdasarkan Jenis Kelamin

\begin{tabular}{|c|c|c|c|}
\hline No & Jenis Kelamin & Jumlah & Prosentase $\%$ \\
\hline 1 & Laki- laki & 5 & $25 \%$ \\
\hline 2 & Perempuan & 25 & $75 \%$ \\
\hline & Jumlah & 30 & 100 \\
\hline
\end{tabular}

Sumber: Hasil Angket 2016.

Tabel 3. Penggolongan Lulusan LKP Yuwita Berdasarkan Tingkat Pendidikan

\begin{tabular}{clcc}
\hline No & \multicolumn{1}{c}{ Kelompok Umur (Tahun) } & Jumlah & Prosentase \% \\
\hline 1 & Tidak tamat SD/sederajat & - & - \\
2 & Tamat SD/sederajat & 2 & $5 \%$ \\
3 & Tidak tamat SMP/sederajat & 3 & $10 \%$ \\
4 & Tamat SMP/sederajat & 20 & $70 \%$ \\
5 & Tidak Tamat SMU/sederajat & 5 & $15 \%$ \\
& Jumlah & $\mathbf{3 0}$ & $\mathbf{1 0 0 \%}$ \\
\hline
\end{tabular}


Tabel 4. Penggolongan Berdasarkan Tujuan Mengikuti Pelatihan Keterampilan

\begin{tabular}{|c|c|c|c|}
\hline No & Alternatif Jawaban & Jumlah & Prosentase $\%$ \\
\hline & $\begin{array}{lll}\text { mendapatkan } & \text { penghasilan }\end{array}$ & & \\
\hline 1 & $\begin{array}{l}\text { keterampilan yang diperoleh melalui latihan } \\
\text { keterampilan menjahit }\end{array}$ & 18 & 60 \\
\hline 2 & Ingin Menambah pengetahuan dan pengalaman & 12 & 40 \\
\hline 3 & Mengisi waktu luang & - & - \\
\hline & Jumlah & 30 & 100 \\
\hline
\end{tabular}

Sumber: Hasil Angket 2016.

Tabel 5. Penggolongan Berdasarkan Motivasi Mengikuti Pelatihan Keterampilan

\begin{tabular}{clccc}
\hline No & & Alternatif Jawaban & Jumlah & Prosentase \% \\
\hline 1 & Ya & & 22 & 73,33 \\
2 & Tidak & & 8 & 26,67 \\
& & Jumlah & $\mathbf{3 0}$ & $\mathbf{1 0 0}$ \\
\hline
\end{tabular}

Sumber: Hasil Angket 2016.

Tabel 6. Penggolongan Berdasarkan Motivasi Instrinsik Mengikuti Pelatihan Keterampilan

\begin{tabular}{clcc}
\hline No & \multicolumn{1}{c}{ Alternatif Jawaban } & Jumlah & Prosentase \% \\
\hline 1 & Murni atas keinginan sendiri & - & - \\
2 & Tidak murni atas keinginan sendiri & 19 & 63,33 \\
3 & Pengaruh orang lain & 11 & 36,67 \\
\multicolumn{2}{c}{ Jumlah } & $\mathbf{3 0}$ & $\mathbf{1 0 0}$ \\
\hline Sumber: Hasil Angket 2016.
\end{tabular}

Sumber: Hasil Angket 2016.

Tabel 7. Penggolongan Berdasarkan Motivasi Dilihat dari Pihak-pihak yang Memberikan Motivasi kepada Para Pemuda-pemudi Putus Sekolah saat menjadi Warga Belajar

\begin{tabular}{clcc}
\hline No & \multicolumn{1}{c}{ Alternatif Jawaban } & Jumlah & Prosentase \% \\
\hline 1 & Pengurus LKP Yuwita Tasikmalaya & 15 & 50 \\
2 & Orang Tua/Keluarga & 12 & 40 \\
3 & Teman & 3 & 10 \\
& & $\mathbf{3 0}$ & $\mathbf{1 0 0}$ \\
\hline
\end{tabular}

Sumber: Hasil Angket 2016. 
Tabe1 8. Penggolongan Berdasarkan Materi Dilihat dari Isi Materi Latihan Keterampilan

\begin{tabular}{clccc}
\hline No & Alternatif Jawaban & Jumlah & Prosentase \% \\
\hline 1 & Lebih menekankan pada praktik & 25 & 83,33 \\
2 & Teori dan praktek seimbang & 5 & 16,67 \\
3 & Banyak teori daripada praktik & Jumlah & $\mathbf{3 0}$ & - \\
& & & $\mathbf{1 0 0}$ \\
\hline
\end{tabular}

Sumber: Hasil Angket 2016.

\section{Proses Pelatihan Keterampilan}

Proses pelatihan keterampilan yang diselenggarakan pada lulusan dalam penelitian ini adalah tata rias pengantin. Pelatihan keterampilan pada dasarnya merupakan suatu proses pembelajaran, yang di dalamnya terjadi adanya suatu proses interaksi manusiawi antara masukan sarana, terutama pendidik dengan masukan mentah yaitu peserta didik (warga belajar). Proses interaksi manusiawi ini merupakan usaha mempersiapkan warga belajar menghadapi lingkungannya, meningkatkan kualitas hidup pribadi yang berlangsung seumur hidup. Karena itu proses pembelajaran mencakup berbagai aspek antara lain adalah tujuan, pendekatan, motivasi, frekuensi kehadiran, materi, metode, media, waktu, fasilitas, instruktur, dan evaluasi. Sehubungan dengan proses pembelajaran pelatihan keterampilan tata rias pengantin di LKP Yuwita Tasikmalaya, maka aspek-aspek tersebut dapat dilihat dari berbagai tabel yang telah tersaji.

Tabel 4 menunjukkan tujuan warga belajar megikuti pelatihan keterampilan di LKP Yuwita sebagian besar yaitu $60 \%$ ingin memperoleh penghasilan dari keterampilan yang dipelajarinya, sedangkan sisanya $40 \%$ bertujuan hanya ingin menambah pengetahuan dan pengalaman. Pada alternatif jawaban ingin mengisi waktu luang ternyata tidak ada yang memilih. Dengan demikian diketahui bahwa sebagian besar warga belajar mengikuti pembinaan melalui latihan keterampilan berorientasi pada dunia kerja, pada akhirnya nanti bekerja sendiri maupun bekerja dengan orang lain. Jadi, pelatihan keterampilan yang dilakukan oleh para warga belajar (pemuda- pemudi putus sekolah) di LKP Yuwita Tasikmalaya dapat dijadikan modal dasar untuk mencari nafkah.

Tabel 5 didapatkan bahwa warga belajar sebagian besar yaitu $73,33 \%$ menyatakan bahwa mereka mengikuti pelatihan keterampilan di LKP Yuwita berdasarkan atas keinginan sendiri (motivasi Instrinsik). Sedangkan sisanya dengan jumlah 26,67\% menyatakan bahwa mereka mengikuti pelatihan keterampilan tata rias pengantin tidak atas dasar keinginan sendiri. Artinya, bahwa mereka kemungkinan mendapatkan dorongan dari pihak lain untuk dapat mengikuti pelatihan keterampilan. Untuk mengetahui apakah mereka mendapatkan dorongan dari orang lain/pihak lain untuk mengikuti pelatihan keterampilan, dapat dilihat pada tabel 6.

Berdasarkan data pada tabel 6, setelah diungkap lebih lanjut, ternyata sebagian besar $63,33 \%$ motivasi yang dimiliki warga belajar tidak murni berdasar atas keinginan sendiri. Demikian pula yang memilih $36,67 \%$ alasan mengikuti pelatihan keterampilan dikarenakan atas dorongan/motivasi dari pihak/orang lain. Untuk membuktikan adanya dorongan oleh orang lain, telah disajikan tabel 7. Didapatkan pada tabel 7 bahwa pihak-pihak/orang-orang yang memberikan motivasi kepada para pemuda-pemudi putus sekolah saat mengikuti pelatihan keterampilan di LKP Yuwita adalah pengurus LKP Yuwita sebesar 50\%, para orang tua/keluarga sebesar $12 \%$ serta teman-teman di lingkungannya hanya 3\%. Dengan demikian dapat dinyatakan bahwa warga belajar pemudapemudi yang putus sekolah saat mengikuti pelatihan keterampilan, mereka memperoleh 
dorongan/motivasi utamanya dari para memilih tetap ada teori dan praktik bisa pengurus LKP Yuwita Kota Tasikmalaya, seimbang. Dengan demikian berarti teori dan kemudian dari keluarga, dan yang paling kecil praktik dapat diserap dengan baik oleh warga adalah dorongan motivasi dari teman.

Tabel 8 mengungkap adanya keinginan lulusan disaat menjadi waga belajar di LKP Yuwita menginginkan materinya lebih menekankan pada praktik. Hal ini dibuktikan yang memilih lebih menekankan para praktik berjumlah $83,33 \%$, sedangkan sisanya $16,67 \%$ belajar dalam arti bahwa LKP dapat menumbuhkan warga belajar untuk mengenal materi pelatihan untuk bisa diwujudkan sebagian besarnya adalah praktik daripada teori. Dan hal ini telah dilakukan oleh LKP Yuwita dalam menyelenggarakan kegiatan pelatihan keterampilan pada tahun-tahun sebelumya.

Tabel 9. Penggolongan Berdasarkan Metode yang Digunakan dalam Menyampaikan Materi

\begin{tabular}{clcc}
\hline No & Alternatif Jawaban & Jumlah & Prosentase \% \\
\hline 1 & Ceramah dan demonstrasi & 22 & 73,33 \\
2 & Ceramah dan tanya jawab & 4 & 13,33 \\
3 & Ceramah dan diskusi & 4 & 13,33 \\
& Jumlah & $\mathbf{3 0}$ & $\mathbf{1 0 0}$ \\
\hline
\end{tabular}

Sumber: Hasil Angket 2016

Tabel 10. Penggolongan Berdasarkan Metode Dilihat dari Penggunaan Metode dengan Pemahaman Terhadap Materi

\begin{tabular}{clcc}
\hline No & \multicolumn{1}{c}{ Alternatif Jawaban } & Jumlah & Prosentase \% \\
\hline 1 & Dapat memahami materi dengan mudah & 20 & 66,67 \\
2 & Kalau disajikan berulang-ulang baru dapat dipahami & 7 & 23,33 \\
3 & Materi sulit untuk dipahami & 3 & 10,00 \\
& Jumlah & $\mathbf{3 0}$ & $\mathbf{1 0 0}$ \\
\hline
\end{tabular}

Sumber: Hasil Angket 2016.

Tabel 11. Penggolongan Berdasarkan Media yang Dilihat dari Cara Belajar

\begin{tabular}{clccc}
\hline No & & Alternatif Jawaban & Jumlah & Prosentase \% \\
\hline 1 & Belajar bersama teman-teman & 18 & 60,00 \\
2 & Bertanya kepada instruktur & 12 & 40,00 \\
3 & Belajar sendiri & Jumlah & - & - \\
\multicolumn{2}{l}{} & & $\mathbf{3 0}$ & $\mathbf{1 0 0}$ \\
\hline
\end{tabular}

Sumber: Hasil Angket 2016. 
Tabel 12. Penggolongan Berdasarkan Instruktur Dilihat dari Hal Kesungguhan dalam Membimbing

\begin{tabular}{clcc}
\hline No & Alternatif Jawaban & Jumlah & Prosentase \% \\
\hline 1 & Sungguh-sungguh & 27 & 90,00 \\
2 & Kurang sungguh-sungguh & 3 & 10,00 \\
3 & Tidak sungguh-sungguh & - & - \\
& Jumlah & $\mathbf{3 0}$ & $\mathbf{1 0 0}$ \\
\hline
\end{tabular}

Sumber: Hasil Angket 2016.

Tabel 13. Penggolongan Berdasarkan Kesempatan Mengakses Pekerjaan

\begin{tabular}{clcc}
\hline No & \multicolumn{1}{c}{ Alternatif Jawaban } & Jumlah & Prosentase \% \\
\hline 1 & Mendapatkan pekerjaan & 27 & 90,00 \\
2 & Belum berhasil mendapatkan pekerjaan & 3 & 10,00 \\
3 & $\begin{array}{l}\text { Sama sekali tidak digunakan untuk mendapatkan } \\
\text { pekerjaan }\end{array}$ & - & - \\
& Jumlah & $\mathbf{3 0}$ & $\mathbf{1 0 0}$ \\
\hline
\end{tabular}

Sumber: Hasil Angket 2016.

Tabel 14. Penggolongan Berdasarkan Penyelenggaraan Pelatihan Keterampilan

\begin{tabular}{|c|c|c|c|}
\hline No & Alternatif Jawaban & Jumlah & Prosentase $\%$ \\
\hline 1 & $\begin{array}{l}\text { Perlu terus diadakan pembinaan melalui pelatihan } \\
\text { keterampilan. }\end{array}$ & 26 & 86,67 \\
\hline 2 & Perlu adanya perubahan dalam bentuk kegiatan. & 4 & 13,33 \\
\hline \multirow[t]{2}{*}{3} & $\begin{array}{l}\text { Tidak perlu diadakan pembinaan melalui pelatihan } \\
\text { keterampilan. }\end{array}$ & - & - \\
\hline & Jumlah & 30 & 100 \\
\hline
\end{tabular}

Dalam menyampaikan materi pelatihan keterampilan, instruktur menggunakan beberapa metoda antara lain ceramah, demonstrasi, tanya jawab dan diskusi. Pada tabel 9 didapatkan metode yang lebih diinginkan adalah metode ceramah yang dikombinasikan dengan demonstrasi yang ditunjukkan sebesar $73,33 \%$. Sedangkan penggunaan metode ceramah yang dikombinasikan dengan tanya jawab dan antara ceramah dengan diskusi masing-masing diperoleh $13,33 \%$. Dengan demikian metode ceramah dan demonstrasi lebih diminati dibanding metode lain yang dapat memberikan kemudahan dalam pelaksanaan pelatihan keterampilan agar berjalan secara praktis dan efektif.

Tabel 10 memberikan arti bahwa apakah penggunaan metode yang diterapkan di LKP Yunita, dapat dipahami materinya. Hasil menunjukkan $66,67 \%$ warga belajar dapat memahami materi dengan mudah. $23,33 \%$ dapat dipahami jika disajikan berulang-ulang, dan sisanya $10 \%$ menjawab materi sulit dipahami. Meskipun hanya terdapat $10 \%$ warga belajar kesulitan untuk memahami materi, maka ini menjadi tugas lembaga beserta instruktur 
pembelajaran untuk memperbaiki proses penyampaian materi agar warga belajar semuanya mampu merasa dengan mudah memahami materi yang disampaikan. Meski demikian, kondisi ini sudah baik karena sebagian besar warga belajar telah mampu memahami materi dengan mudah. Selain itu, penggunaan metode juga dapat mempengaruhi pemahaman warga belajar terhadap materi yang disajikan, karena metode yang sesuai dengan warga belajar akan sangat membantu warga belajar agar lebih memahami materi. Dapat dikatakan metode sebagai alat untuk menciptakan hubungan interaksi yang eduktif. Yang pasti menurut Kamil (2010), materi harus disesuaikan dengan tingkat kemampuan dan latar belakang warga belajar.

Tabel 11 menggambarkan kondisi lulusan pada waktu menjadi warga belajar di LKP Yuwita mengenai kegiatan belajarnya. Prosentase terbesar 60\% mereka belajar bersama teman-temannya. Sedangkan sisanya $40 \%$ mereka belajar melalui bertanya kepada instrukturnya, karena pilihan belajar sendiri ternyata tidak terpilih oleh mereka. Ini berarti mereka saat mengikuti pelatihan tidak ada yang belajar sendiri. Dengan demikian, warga belajar yang mengikuti pelatihan keterampilan sebagian besar belajarnya bersama teman dibanding dengan instruktur bahkan belajar sendiri apalagi. Barangkali belajar bersama teman dapat lebih memudahkan tugas-tugas, karena pada dasarnya berbicara dengan teman akan memberi keleluasaan untuk mengemukakan pendapat dengan bahasa sehari-hari (tidak formal) disbanding berbicara dengan instrukturnya.

Tabel 12 merupakan penggolongan opini lulusan saat menjadi warga belajar di LKP Yuwita terkait kesungguhan instruktur dalam membimbing. Tugas instruktur dalam pembinaan pelatihan keterampilan dituntut dapat membimbing warga belajar dengan baik. Dilihat dari hal kesungguhan instruktur dalam membimbing diperoleh bahwa sebesar 90\% lulusan menjawab instruktur telah bersungguh sungguh. Sedangkan yang menjawab bahwa istruktur kurang bersungguh-sungguh sebesar $10 \%$, sedangkan yang menjawab bahwa instruktur tidak bersungguh-sungguh tidak ada yang memilih. Ini berarti instruktur yang ada di LKP Yuwita telah melaksanakan tugasnya dengan sebaikmungkin. Sebagai bukti bahwa hampir 100\% mereka (lulusan) menganggap instruktur telah bersungguh-sungguh dalam memberikan bimbingannya atau melakukan proses pembinaan dengan baik. Hal ini juga menggambarkan bahwa proses pelaksanaan pelatihan keterampilan di LKP Yuwita sangat didukung oleh kemampuan para instruktur yang bersungguh-sungguh dalam menjalankan tugasnya atau dalam membimbing para warga belajar. Dengan demikian, maka keberhasilan LKP Yuwita dalam menghasilkan lulusan yang berkompeten di bidang keterampilan akan lebih dapat tercapai. Sebagaimana yang dikemukakan Moekijat (1991) bahwa tujuan pelatihan untuk mengembangkan pengetahuan dan sikap sehingga dapat menimbulkan kemauan untuk bekerjasama.

Tabel 13 mengungkapkan bahwa lulusan setelah mengikuti pelatihan keterampilan apakah langsung terserap dalam dunia kerja atau bahkan tidak sama sekali. Didapat 90\% lulusan mendapatkan pekerjaan, sedangkan sisanya $10 \%$ belum berhasil mendapatkan pekerjaan meskipun telah berusaha. Adapun item sama sekali tidak digunakan untuk mendapatkan pekerjaan tidak satu pun lulusan memilih pilihan ini. Hal ini dapat dianggap sebagian besar lulusan telah mendapatkan pekerjaan. Dengan demikian, proses penyelenggaraan pelatihan keterampilan dianggap tepat sasaran dan tepat guna, hal ini dibuktikan hampir secara keseluruhan lulusan telah mendapatkan pekerjaan. Dapat disampaikan pula bahwa warga belajar mempunyai sikap optimis, dengan bekal keterampilan yang dimilikinya akan mendapatkan pekerjaan. Hal ini menunjukkan pula bahwa mereka memiliki sikap mental yang ingin maju yaitu berkemauan dan berkeyakinan tinggi. Dengan demikian, maka keterampilan yang diberikan telah mampu membina mental warga belajar dan juga mendapatkan peluang kerja di tengah-tengah masyarakat.

Tabel 14 bermaksud mengungkap keberlanjutan program yang diselenggarakan 
LKP Yuwita. Didapatkan 86,67\% menginginkan bahwa LKP Yuwita perlu terus mengadakan pembinaan pelatihan keterampilan, terutama bagi pemuda-pemudi putus sekolah. Adapun sisanya $13,33 \%$ menginginkan tetap ada pelatihan keterampilan, tetapi perlu adanya perubahan dalam bentuk kegiatan yang diselenggarakan. Hal ini maksudnya adalah LKP Yuwita perlu menyeleggarakan program lainnya. Sebagai contoh, bahwa pernah diadakan pelatihan keterampilan tata rias pengantin, maka perlu diadakan pelatihan lain selain tata rias pengantin, apakah itu menjahit, potong rambut bahkan yang lainnya yang dapat diakses dengan mudah dalam pangsa pasar. Dengan demikian dapat dikatakan bahwa LKP Yuwita perlu mengadakan pelatihan keterampilan secara berkelanjutan. Program pelatihan keterampilan diutamakan dapat menyentuh para pemuda-pemudi putus sekolah untuk dapat mengikuti kegiatan pembinaan melalui pelatihan keterampilan di LKP Yuwita. Upaya pembinaan bagi para pemuda-pemudi putus sekolah melalui berbagai pelatihan keterampilan merupakan usaha menggali dan mengembangkan potensi yang dimiliki oleh pemuda-pemudi putus sekolah tersebut, sehingga berkembang semaksimal mungkin untuk mewujudkan kemampuan dan terpenuhinya kebutuhan diri guna menjalani masa depannya.

Hasil penelitian yang didapat ini dijadikan sebagai analisis kebutuhan yang dapat dijadikan prosedur penyelenggaraan kegiatan. Seperti yang diungkap Kamil (2012), prosedur pelatihan dimulai dengan analisis kebutuhan yang menjadi pangkal utama dalam penyusunan program pelatihan. Hasil tersebut kemudian dilanjutkan dengan penyusunan kriteria keberhasilan sebagai tolok ukur kesuksesan penyelenggaraan suatu pelatihan. Seperti Guerci, Bartezzaghi, \& Solari (2010) menegaskan evaluasi sangat penting setidaknya untuk dua alasan. Satu sisi untuk merencanakan sistem evaluasi yang bertujuan untuk memenuhi kebutuhan penyelenggaraan yang terkait, dan sisi lain untuk menyorot kemungkinan berbagai perumusan kebijakan pemangku kepentingan.
Lembaga kursus dan pelatihan (LKP) merupakan lembaga yang bergerak dalam lingkup pendidikan nonformal. Sebagaimana lembaga yang sejenis, yakni pusat kegiatan belajar masyarakat (PKBM). Akan tetapi, syarat mutlak yang harus ada di PKBM setidaknya mencakup minimal tiga program, yaitu kesetaraan, keaksaraan dan pendidikan anak usia dini (PAUD). Jika tiga program terselenggarakan, maka di PKBM dapat membuka program lain diantaranya program kursus dan pelatihan. Sebagaimana penelitian yang dilakukan Raharjo, Suminar, \& Muarifuddin (2016) mengungkap program yang diselenggarakan PKBM di Jawa Tengah berupa program PAUD, Kesetaraan, Keaksaraan, Kursus Dan Pelatihan, Kelompok Belajar Usaha (KBU), dan Magang. Adapun program yang paling digemari adalah banyak ragamnya adalah program kursus dan pelatihan. Hal ini tentu berbeda antara LKP dengan PKBM. Jika kursus dan pelatihan di PKBM itu termasuk program, sedangkan di LKP, kursus dan pelatihan itu adalah sebutan dari lembaga pendidikan.

\section{SIMPULAN}

Penelitian melibatkan lulusan yang telah memiliki usia produktif. Sebagian besar terdiri dari perempuan berpendidikan rata-rata jenjang SMP. Alasan mereka mengikuti pembinaan pelatihan keterampilan adalah ingin bekerja untuk mendapatkan penghasilan. Motivasi tumbuh secara instrinsik, tetapi tidak murni atas keinginan sendiri, yangmana lebih banyak dipengaruhi oleh pengurus lembaga. Adapun materi yang diinginkan dalam penyelenggaraan pelatihan keterampilan lebih menekankan pada praktik. Metode menggunakan ceramah dan demonstrasi. Sebagaiamana materi dan metode yang diinginkan tersebut, sebelumnya telah diterapkan oleh lembaga. Dengan metode dan materi yang demikian, mereka sebagian besar dapat memahami materi dengan mudah. Cara belajar mereka lebih condong pada belajar bersama teman daripada bertanya pada instruktur maupun belajar sendiri. Demikian pula instruktur telah membimbing dengan sungguh-sungguh dalam melaksanakan kegiatan 
pelatihan keterampilan. Sebagian besar pula mereka telah mendapatkan pekerjaan dan menginginkan LKP Yuwita dapat menyelenggarakan pelatihan keterampilan secara berkelanjutan.

Apa yang telah dikemukakan oleh lulusan, hendaknya dapat dijadikan bahan evaluasi demi keberlanjutan pengelolaan lembaga. Dengan demikian, penyelenggaraan lembaga dapat memenuhi kebutuhan masyarakat yang utamanya berorientasi pada daya serap lulusan terhadap kebutuhan pasar kerja.

\section{DAFTAR PUSTAKA}

Anwar. (2004). Pendidikan kecakapan hidup: (Life skills education). Bandung: Alfabeta.

Guerci, M., Bartezzaghi, E., \& Solari, L. (2010). Training evaluation in Italian corporate universities: A stakeholder-based analysis.
International Journal of Training and Development, 14(4), 291-308.

International Commission on Education for the Twenty-First Century, \& Delors, J. (1996). Learning, the treasure within: Report to UNESCO of the international commission on education for the twenty-first century: Highlights. Paris: Unesco Pub.

Kamil, M. (2012). Model pendidikan dan pelatihan (konsep dan aplikasi). Bandung: Alfabeta.

Moekijat. (1991). Latihan dan pengembangan sumber daya manusia. Bandung: Mandar Maju.

Raharjo, T. J., Suminar, T., \& Muarifuddin, M. (2016). Peran Pusat Kegiatan Belajar Masyarakat dalam Menanggulangi Kemiskinan melalui Pendidikan Nonformal di Jawa Tengah. Journal of Nonformal Education, 2(1), 21-38.

Surakhmad, W. (1979). Metodologi pengajaran nasional. Bandung: Jemmars. 